This is an electronic reprint of the original article. This reprint may differ from the original in pagination and typographic detail.

Author(s): Bloom, Jessica de; Rantanen, Johanna; Tement, Sara; Kinnunen, Ulla

Title: $\quad$ Longitudinal Leisure Activity Profiles and Their Associations with Recovery Experiences and Job Performance

Year: $\quad 2018$

Version:

Please cite the original version:

Bloom, J. D., Rantanen, J., Tement, S., \& Kinnunen, U. (2018). Longitudinal Leisure Activity Profiles and Their Associations with Recovery Experiences and Job Performance. Leisure Sciences, 40(3), 151-173.

https://doi.org/10.1080/01490400.2017.1356254

All material supplied via JYX is protected by copyright and other intellectual property rights, and duplication or sale of all or part of any of the repository collections is not permitted, except that material may be duplicated by you for your research use or educational purposes in electronic or print form. You must obtain permission for any other use. Electronic or print copies may not be offered, whether for sale or otherwise to anyone who is not an authorised user. 


\section{Longitudinal leisure activity profiles and their associations with recovery experiences and job performance}

Jessica de Bloom ${ }^{1}$, Johanna Rantanen ${ }^{2}$, Sara Tement ${ }^{3} \&$ Ulla Kinnunen ${ }^{4}$

${ }^{1}$ Jessica de Bloom, Institute for Advanced Social Research, FI-33014 University of Tampere, Finland, jessica.de.bloom@uta.fi, tel: +358 503186070 (corresponding author)

${ }^{2}$ Johanna Rantanen, Department of Teacher Education, University of Jyväskylä, P.O. Box 35, FI-40014 University of Jyväskylä, Finland, k.johanna.rantanen@jyu.fi

${ }^{3}$ Sara Tement, Department of Psychology, University of Maribor, Slovenia, sara.tement@um.si

${ }^{4}$ Ulla Kinnunen, School of Social Sciences and Humanities, FI-33014 University of Tampere, Finland, ulla.kinnunen@uta.fi

Key words:

free time, leisure activities, recovery, job performance, work, off-job activities

Running title:

Leisure activity profiles, recovery and performance

Accepted for publication in Leisure Sciences. This paper is not the copy of record and may not exactly replicate the final, authoritative version of the article. Please do not copy or cite without authors permission.

Acknowledgements:

This work was supported by the Academy of Finland (grant no. 257682) as part of a larger research project entitled: "Recovery from job stress: Integrating perspectives of work and environmental psychology". 


\title{
Longitudinal leisure activity profiles and their associations with recovery experiences and job performance
}

\begin{abstract}
We aimed to identify longitudinal leisure activity profiles among working adults and their links to recovery experiences and job performance. Leisure activities, recovery experiences, and job performance were investigated in 831 employees using survey data collected in spring 2013 (T1) and 2014 (T2). Through latent profile analysis (LPA) four stable longitudinal leisure activity profiles were identified. "Social Sports(wo)men" (46\%) engaged in physical and social activities, but rarely in creative or cultural activities. "Active Artists" (23\%) pursued all leisure activities, particularly creative activities. "Socially \& Culturally Inactives" (17\%) exercised frequently, but seldom engaged in social, cultural or creative activities. "Inactive Soloists" (14\%) spent little time on physical activities. "Active Artists" reported most beneficial recovery experiences and job performance. Our results corroborate the importance of leisure activities (particularly diverse and creative activities) in facilitating recovery from work stress and job performance.
\end{abstract}

Key words:

free time, leisure activities, recovery, job performance, work, off-job activities

Running title:

Leisure activity profiles, recovery \& performance 


\section{Longitudinal leisure activity profiles and their associations \\ with recovery experiences and job performance}

Leisure and work are closely interconnected spheres of life (e.g., Hilbrecht, 2007; Stebbins, 2015). Availability of leisure time and engagement in pleasant leisure activities have been associated with enhanced health and well-being (e.g., Blasche, Arlinghaus, \& Dorner, 2014; Brajša-Žganec, Merkaš, \& Šverko, 2011; Christiansen \& Matuska, 2006; Kuykendall, Tay, \& Ng, 2015; Mannell, 2007; Newman, Tay, \& Diener, 2014; Sonnentag, Arbeus, Mahn, \& Fritz, 2014; Zawadzki, Smyth, \& Costigan, 2015). Longer periods of off-job time and engagement in leisure activities are expected to buffer the link between job stress, acute bodily stress reactions, and chronic health impairment (Geurts \& Sonnentag, 2006). In leisure sciences, this process has been referred to as "leisure coping" (Iwasaki \& Schneider, 2003). According to Iwasaki and Mannell (2000), leisure fulfills two major functions in coping with stress. Firstly, it acts as a buffer which attenuates the relationship between stress and health referred to as "leisure coping beliefs". These generalized beliefs represent rather stable dispositions. Secondly, "leisure coping strategies" can be seen as mediators. These strategies constitute actual behaviors or cognitions available through engagement in leisure which help people to cope with stress and maintain good health. Leisure coping strategies are more situation specific and intentional than leisure coping beliefs. Leisure activities allow stressed individuals gain energy and perspective and to feel refreshed which in turn helps them to better deal with stressors (Iwasaki, 2002). Accordingly, leisure can be considered an essential aspect of a satisfying (working) life and understanding the links between leisure and work is crucial. Surprisingly, there has so far been little research on the connection between leisure activities and work outcomes. Accordingly, we set out to investigate the relation between engagement in specific sets of leisure activities, recovery from job stress and job performance. 
Using a longitudinal research design with two measurement points and a one-year time lag in a large sample of employees, we first aimed to identify people with similar patterns of typical leisure activities (i.e., physical, social, creative, and cultural activities) both at Time 1 and Time 2 with a 12 months' time gap in between, thereby identifying longitudinal leisure activity profiles across time and not just within one, cross-sectional time point. Secondly, we examined if and how these longitudinal leisure activity profiles differed in recovery experiences (i.e., psychological detachment, relaxation, control and mastery experiences during off-job time) across a 12-months period. Thirdly, we investigated whether leisure activity profiles differed regarding job performance (i.e., task-, contextual-, and adaptive performance) over time.

This study at the intersection of leisure science and work psychology aims to provide three new perspectives on the connection between leisure and work. Firstly, it provides a holistic perspective on leisure activities. Instead of focusing on the impact of each isolated leisure activity on recovery and job performance, we seek to identify characteristic leisure activity profiles, in which different leisure activities combine and describe a totality of an individual's leisure activities. People may engage in several activities during their leisure and find them equally meaningful instead of emphasizing one over other. Hence, also successful recovery and job performance may depend on certain patterns of activities rather than on one single activity. This will lead to an advanced understanding of the relation between concrete sets of leisure activities and important work-related outcomes. Secondly, we use a longitudinal research design with two measurement waves encompassing a one-year period. This affords a longitudinal perspective on leisure activity engagement over a prolonged time span. Thirdly, our study integrates theories and insights from the hitherto separate research fields of leisure sciences and work psychology, resulting in a multidisciplinary perspective. 


\section{Leisure activities and work outcomes}

Empirical studies on leisure activities, recovery from job stress and work-related outcomes are scarce and have thus far been inconclusive. For instance, social leisure activities correlated with lower levels of burnout (Sonnentag, 2001), but were unrelated (De Bloom et al., 2011) or even detrimental to recovery from stress in other studies (Rook \& Zijlstra, 2006). In a five-day diary study by Sonnentag (2001) in 100 teachers, low-effort activities supported recovery from work while Rook and Zijlstra found opposite effects in their seven-day diary study in 46 employees (2006). Cultural leisure activities were associated with work engagement (Tuisku, Pulkki, Back, Ahola, Hakanen, \& Virtanen, 2012), health and well-being, but their impact seemed to depend on age and gender in a study published by Cuypers et al. (2011). Creative leisure activities have rarely been investigated and it is largely unclear whether they impact work-related outcomes. The few existing studies suggest positive relations with mental and physical health, likewise life satisfaction and work engagement (e.g., Waterman, 2005; Winwood, Bakker, \& Winefield, 2007). Most conclusive evidence is available for physically active leisure which has been associated with less stress, fewer depressive symptoms (Goodman, Geiger, \& Wolf, 2015; Penedo \& Dahn, 2005), and better health (Hansmann, Hug, \& Seeland, 2007; Iwasaki, Zuzanek, \& Mannell, 2001). Still, some studies showed no relations between engagement in physical leisure activities and lower levels of negative affect (Feuerhahn, Sonnentag \& Woll, 2013) or health and well-being (De Bloom, Geurts \& Kompier, 2012).

Due to the scattered, complicated picture emerging from earlier research (which may also result from differences in research designs, methods and scientific rigor), scholars have concluded that it may not be the activity per se which matters for recovery from work stress, but the subjective experience associated with leisure activities, labeled "recovery experiences" (Sonnentag \& Fritz, 2007). Consequently, in work psychology and particularly in the research 
field "recovery from work stress", the focus has shifted from examining leisure activities to subjective experiences. However, human cognition is dependent on bodily interaction with the environment including motor control and sensory processing (Wilson, 2002). Concrete activities (or behaviors) lie at the very base of human experience and changes in subjective experiences depend on changes in activities. Accordingly, we believe that it is important to investigate the role of concrete activities as precursors of subjective experiences and other (work) outcomes.

So far, most studies on leisure activities and recovery from job stress have investigated the effect of certain leisure activities in isolation, ignoring the possibility that people may engage in many activities during their leisure time, leading to unique outcomes. In analyzing leisure activities separately (variable-oriented approach), meaningful heterogeneity between persons may be missed (Wang \& Hanges, 2011). Using a person-oriented approach instead, we will study whether "the whole is indeed greater than the sum of its parts" and assess whether and how combinations of specific leisure activities relate to working people's recovery experiences and job performance. Leisure activities deserve closer research attention as they form the behavioral basis for subjective recovery experiences. Accordingly, this study contributes to a recently published study using the person-oriented approach to reveal patterns of recovery experiences (Bennett, Gabriel, Calderwood, Dahling, \& Trougakos, 2016) and their relation to well-being outcomes by adding the behavioral component (i.e., leisure activities) as the basis to the person-oriented analyses.

\section{Leisure activity profiles}

Off-job time can be spent on various activities ranging from work-related (e.g., working overtime) and household tasks to perhaps more preferred and enjoyable leisure activities such as sports, socializing or attending cultural events. Researchers have therefore suggested 
distinguishing between "respite" and "chores" during leisure time. Whereas respite refers to restful and pleasant activities, chores are burdensome, non-preferred activities (Trougakos, Beal, Green, \& Weiss, 2008). This study focuses on "respite", in line with conceptualizations of leisure defined as freely available, self-determined non-productive time spent in noncompulsory activities and away from work-related or domestic chores and obligations (e.g., Argyle, 1996; Iso-Ahola, 1979; Sonnentag 2001; Stebbins, 2001).

More specifically, we investigate whether engagement in different leisure activities leads to characteristic combinations of leisure activities, that is, to typical leisure activity profiles to which individuals belong. We used Latent Profile Analysis (LPA) for this purpose. LPA is a statistical method of analysis used in conjunction with a person-centered approach which is fundamentally different from the traditional, widely-used variable-centered approach (e.g., Bergman \& Lundh, 2015). LPA's purpose resembles cluster analysis, that is, to sort individuals into categories similar to each other and different from those individuals in other categories. Compared to cluster analysis, LPA is a model-based analysis method and provides fit indices to compare different group-solutions (or "profiles") with each other using consistent statistical criteria in order to determine the best fitting solution (Wang, Sinclair, Zhou, \& Sears, 2013). By investigating characteristic combinations of leisure activities, LPA afforded us a more dynamic view of engagement in diverse leisure activities occurring within the same narrow time span. LPA also helped us to gain a new perspective on the rather fragmented picture of the relationships between leisure, recovery and performance emerging from earlier research which studied the impact of each leisure activity separately.

To the best of our knowledge person-centered analysis has only been applied once in leisure research. In this study, seven different profiles were identified in a cross-sectional study design with a student sample. The profiles differed in vocational as well as in leisure interests and clear profiles of above-average social and artistic leisure interests were found along with a 
profile of above-average interests in all types of leisure (Leuty et al., 2015). Accordingly, it can be assumed that people differ in the intensity with which they engage in leisure activities. Whilst this earlier study examined leisure interests (rather than actual engagement in behavior) and similarities to vocational interests, the relationship between the profiles and recovery from work or work outcomes have not been examined.

Our study design broadens this earlier study as we were able to investigate the existence of longitudinal leisure activity profiles reflecting possible stable orientation towards one's leisure activity preferences and participation. Based on earlier research we expected that general preferences for certain types of leisure activities are relatively well developed and fairly stable in adults, even though the intensity of engagement in leisure activities may vary between days (e.g., Friedman, Martin, Tucker, Criqui, Kern, \& Reynolds, 2008; Iso-Ahola, Jackson, \& Dunn, 1994; Iwasaki \& Mannell, 2000). We also expected to find profiles differing in both intensity (low-high) and variety (type) of leisure activities. As LPA is a method intended to capture unknown but true population heterogeneity by revealing qualitatively different subpopulations within the data (Wang et al., 2013) we do not propose specific hypotheses about the expected profiles. To arrive at a better understanding of the emerging profiles, we also examined differences in demographic variables (i.e., gender, marital status, education, occupational status, age, number of children living at home, weekly working hours) between the members of the different profiles.

\section{Leisure activities and recovery experiences}

Leisure is vital for employees to recover from the demands of work. According to the effortrecovery model (Meijman \& Mulder, 1998), respite from work needs to take place after work so as to replenish a person's psychological and psychophysiological resources. Accordingly, investing time and energy in activities that deplete the same resources already used at work 
(e.g., cognitive or physical) may hamper the recovery process. If the recovery process is incomplete due to engagement in unpleasant, burdensome activities or too short periods of free time, load effects build up (i.e., prolonged fatigue, sleeping problems, or physical complaints) with adverse health consequences in the long-term such as diabetes, burnout or depression as well as performance decrements (Beckers et al., 2004; Dahlgren, Kecklund, \& Åkerstedt, 2006; Sluiter, De Croon, Meijman, \& Frings-Dresen, 2003).

Despite these rather strong theoretical underpinnings, research on the link between leisure activities and recovery from work is still in its infancy (e.g., Demerouti, Bakker, Geurts, \& Taris, 2009, for a review). According to Sonnentag and Fritz (2007), leisure activities promote recovery from work by enabling so-called recovery experiences, consisting of psychological detachment, relaxation, control, and mastery. The first two experiences are theoretically grounded in the effort-recovery model (Meijman \& Mulder, 1998). The basic idea is that mental disengagement from work and low psycho-physiological arousal activities help people to regain their individual homeostasis set point or baseline. The third experience, control, is rooted in self-determination theory (Ryan \& Deci, 2000). It entails decision latitude and constitutes an essential mechanism in fostering intrinsic motivation and well-being. The fourth experience, mastery, encompasses activities that challenge individuals and provide learning opportunities. It is grounded in flow theory (Csikszentmihalyi, 1991) and Stebbin's (2001) serious leisure perspective. Below we provide an overview of the existing theoretical and empirical evidence for the suggested link between leisure activities and recovery experiences.

It is well established that physical activities are beneficial to physical health, mood, and psychological recovery indicators (Demerouti et al., 2009; Reed \& Ones, 2006; Rook \& Zijlstra, 2006). Exercise may promote positive feelings about oneself, enhance the secretion of neurotransmitters with an antidepressant effect and distract from daily hassle and job-related thoughts (Hansen, Stevens, \& Coast, 2001; Sonnentag \& Jelden, 2009). Several empirical 
studies have indeed shown that physical activities during off-job time are connected to high levels of psychological detachment from work (e.g., Feuerhahn, Sonnentag, \& Woll, 2014; Ten Brummelhuis \& Bakker, 2012). Intensive physical activities such as sports and exercise are also prototypical examples of mastery experiences as they typically involve facing physical challenges and learning new skills (Hahn, Binnewies, Sonnentag, \& Mojza, 2011). Here we also focus on physical activities in natural surroundings, as these activities may have additional benefits in terms of recovery from work (Korpela \& Kinnunen, 2011). Numerous studies have demonstrated that natural environments have the potential to alleviate stress and mental fatigue (e.g., Brown et al., 2010; Berman, Jonides, \& Kaplan, 2008; Richardson et al., 2016).

The desire to be with others and engage in social activities is an inborn, evolutionary adaptive human need (e.g., Baumeister \& Leary, 1995). Social activities enhance social support and improve health and well-being in humans from childhood to late adulthood (e.g., Dormann \& Zapf, 1999; Hale, Hannum, \& Espelage, 2005). Social support may also function as a stress buffer, for instance, by lowering cardiovascular reactivity to psychosocial stress (e.g., Gerin, Pieper, Levy, \& Pickering, 1992). Social support may also explain why having multiple roles is beneficial for individuals (Barnett \& Hyde, 2001). In line with this reasoning, Ten Brummelhuis and Bakker (2012) found that social activities during off-job time correlate positively with mental detachment from work and with relaxation.

Cultural activities such as going to concerts or museums have been described as "sensual engagement" and "cognitive stimulation" (Tinsley \& Eldredge, 1995). As such activities are mentally engaging, they may promote psychological disengagement from work as well. Moreover, these activities usually require relatively low levels of mental or bodily activation, which may stimulate relaxation experiences. To the best of our knowledge, only one study has so far addressed the link between cultural activities and recovery experiences. In this crosssectional study among hospital employees, regular engagement in cultural leisure activities on 
a weekly basis was related to relaxation, mastery, and control experiences during off-job time (Tuisku, Virtanen, De Bloom, \& Kinnunen, 2016).

Creative activities like painting, music making or handicrafts entail actively producing something (e.g., pictures, music or embroidery), possibly resulting in feelings of mastery and control. Creative production also demands cognitive and/or physical attention, leaving little cognitive space for rumination about work, which should manifest in high levels of mental detachment. Correspondingly, Eschleman and colleagues (2014) found that creative activities predicted mastery and control. However, they also found links to relaxation but, contrary to expectations, they found no association between creative leisure activities and mental detachment from work. Summing up, the few results so far suggest that specific leisure activities vary in their potential for liberating recovery experiences (see also Pressman et al., 2009; Sonnentag \& Fritz, 2007; Tucker, Dahlgren, Åkerstedt, \& Waterhouse, 2008).

\section{Leisure activities profiles and job performance}

In general, job stress is related to poor job performance (e.g., Demerouti, Taris, \& Bakker, 2007; Gilboa, Shirom, Fried, \& Cooper, 2008). Leisure is essential to replenish a person’s cognitive and emotional resources (Volman, Bakker, \& Xanthopoulou, 2012) to meet job performance requirements. Job performance is defined as " [...] scalable actions, behavior and outcomes that employees engage in or bring about that are linked with and contribute to organizational goals" (Koopmans et al., 2011, p. 216). Job performance includes task-, contextual-, and adaptive performance. Task performance refers to a person's work actions that directly contribute to an organization's core business (Motowidlo \& Van Scotter, 1994). Contextual performance is defined as employees' behaviors that go above and beyond the tasks strictly required by the job description, such as helping co-workers and volunteering for additional work (Koopmans et al., 2011). Adaptive performance refers to creative thinking or 
"[...] the ability of an individual to change his or her behavior to meet the demands of a new environment" (Charbonnier-Voirin \& Roussell, 2012, p. 1). Whereas individual task performance forms the basis of each company's functioning, contextual and adaptive performance, reflected in motivation and the ability to "go the extra mile", to flexibly adjust to today's rapidly changing working realities, and to evince novel, creative solutions to important work problems, greatly determine a company's success and competitive edge.

Research has so far established very few connections between engagement in leisure activities and job performance. This may partly be due to the separation of the research fields of leisure sciences and work psychology. Theoretical associations between leisure and work are complex (e.g., Amstad \& Semmer, 2009). In the work-life balance literature, five different models have been used to explain the relationship between work and non-work life: segmentation, spillover, compensation, instrumental and conflict (Guest, 2002). Segmentation assumes that the work and non-work are separate life domains that do not influence each other, whereas spillover presumes that the two spheres of life can influence each other positively and negatively. Compensation entails the idea that a deficit in one domain can be made up by the other and the instrumental model claims that activities in one life domain can facilitate success in the other. Finally, the conflict model states that both life domains entail roles with high demands which results in difficult choices and potentially conflict (see also O'Driscoll, 1996; Zedeck \& Mosier, 1990). These descriptive models derive from different research traditions, the models' possible propositions vary in their level of precision and the distinction between the models is not straightforward. For instance, compensation and conflict can be seen as positive spillover or negative spillover respectively.

There is some empirical evidence from a diary study showing that people who feel wellrested in the morning report higher levels of task- and contextual performance later that day (Binnewies, Sonnentag, \& Mojza, 2009a; Sonnentag, 2003). Furthermore, Binnewies, 
Sonnentag and Mojza (2009b) found that feeling recovered during leisure predicted an increase in self-reported task performance after six months. Another diary study reported that a lack of social activities during the weekend predicted poor task performance after the weekend (Fritz \& Sonnentag, 2005). In addition, a recent study on active duty captains in the US Air Force showed that engagement in creative leisure activities positively affected self-rated job creativity, as well as other-rated creative job performance and organizational citizenship behaviors (Eschleman et al., 2014). Following this line of reasoning, engagement in leisure activities may constitute an important resource, which is highly relevant from an employer's perspective as it may affect employees' job performance and companies' success.

According to Chick and Hood (1996), a person's tendency to actively engage in leisure activities during free time may be reflected in attitudes and interests at work. As there seems to exist a "[...] fundamental similarity between what occurs in occupational environments and what transpires elsewhere" (Staines, 1980, p. 112), it can be assumed that employees who enjoy active leisure may also be highly engaged and active at work, resulting in better job performance. Conversely, employees inclined to be passive in their free time and not purposefully involved in any leisure activities may also be more passive at work, for example in terms of less personal initiative and creativity.

Purposely engaging in pleasant, self-selected leisure activities may replenish and create resources conducive to concentrating on and investing effort in one's work, resulting in better performance. A resourceful person will also more likely invest resources in additional work tasks, which should manifest in better contextual performance. Active leisure activities may also stimulate employees to explore the world around them, to experiment, and play (Fredrickson, 2000). This behavior and the resulting diverse input from the environment may in turn lead to higher levels of adaptive performance as predicted by the neural network model of creativity (Martindale, 1999). Accordingly, it can be speculated that workers whose leisure 
is characterized by a wide range of leisure activities and frequent purposeful engagement in leisure might perform better at work than employees who engage in only in a few leisure activities occasionally.

Summing up and closing the gaps of existing studies, we address the following three research questions in this study:

1) Can we distinguish employees based on their longitudinal characteristic profiles of engagement in leisure activities (i.e., high or low frequency of engagement in specific activities)?

2) Do longitudinal leisure activity profiles differentially relate to recovery experiences (i.e., psychological detachment, relaxation, mastery and control)?

3) Do longitudinal leisure activity profiles differentially relate to job performance (i.e., task-, contextual, and adaptive performance)?

\section{Method}

\section{Participants and procedure}

The participants of the present study were 831 Finnish employees from 12 different organizations. The electronic questionnaire data were collected in spring 2013 (T1) and 2014 (T2). Of all employees contacted $(N=3,593), 1,347$ returned the completed questionnaire after two reminders. At T2, 831 of these employees also returned the second questionnaire, yielding a response rate of $62 \%$. Of these participants $59 \%$ were women, mean age was 47 years $(S D=$ 10.02, range 21-67). The majority was cohabiting with a partner (80\%) and about half had children living with them (43\%, mean for those with children was $2, S D=0.84$, range $1-7)$. Most participants were highly educated: $64 \%$ percent of the sample held a bachelor's or higher university degree. Most of them (58\%) worked in upper white-collar occupations, $30 \%$ in lower white-collar occupations, $8 \%$ in blue-collar occupations and $4 \%$ in higher administrative or 
managerial occupations. Almost all participants (97\%) were employed full-time, working 39 hours per week $(S D=5.94$, range 12-60).

Attrition analyses showed that the participants (i.e., those providing data at T1 and T2) did not differ from the participants who only responded to the first questionnaire in terms of gender, age, marital status, number of children or education. However, participants were more often employed as higher white-collar workers (58\% vs. 50\%) than the non-respondents ( $p<$ $.05)$ and more often had a permanent employment contract ( $89 \%$ vs. $79 \%$ ) than the nonrespondents $(p<.001)$. Participants also worked longer hours per week (39.1 vs. 37.9 hours, $p$ $<.01)$ and more often worked a regular day shift $(90 \%$ vs. $83 \%, p<.01)$ than did the nonrespondents.

\section{Measures}

Leisure activities. In leisure research, different classifications of leisure activities have been used ranging between three (Passmore \& French, 2001) and 11 different categories (Tinsley \& Eldredge, 1995). As result, there is no agreement about the most suitable taxonomy for leisure activities (Brajša-Žganec et al., 2011). Existing scales for measuring leisure activity participation have often been too specific, too detailed or focused on leisure preferences or satisfaction instead of the frequency of engagement in certain leisure activities. Therefore, we assessed a small number of categories used in earlier studies within occupational health psychology (e.g., De Bloom, Geurts, \& Kompier, 2013; Demerouti et al., 2009; Rook \& Zijlstra, 2006; Sonnentag, 2001). These categories also roughly correspond to the types of activities suggested by Tinsley and Eldredge (1995) after cluster analyzing 82 different free time activities (ranging from hunting to collecting autographs). Accordingly, we asked participants to report at both measurement points ( $\mathrm{T} 1$ and $\mathrm{T} 2$ ) how often they spent their free time on the following activities: Intensive physical activities (according to WHO guidelines, 
defined as exercising at least 20 minutes getting at least slightly out of breath and sweating), physical activities in natural surroundings (e.g., swimming, running, cycling), social activities (e.g., dinner with friends/family, playing games, meeting friends in person/online), cultural activities (e.g., going to museums, concerts, theaters) and creative activities (e.g., painting, music making, handicrafts). Response options were: 1 = hardly ever or a few times per year, 2 $=$ about once per month, $3=$ a few times per month, $4=$ about once per week, $5=$ a few times per week and $6=$ almost every day. These single measures represent formative measures (implying no need for internal consistency).

Recovery experiences. The four facets of recovery experiences, psychological detachment, relaxation, mastery, and control were measured at $\mathrm{T} 1$ and $\mathrm{T} 2$ using a well-validated Finnish version of the Recovery Experience Questionnaire (Sonnentag \& Fritz, 2007; Kinnunen, Feldt, Siltaloppi, \& Sonnentag, 2011). Each scale consisted of three items and participants were asked to respond with respect to their off-job time on a five-point scale ranging from 1 (totally disagree) to 5 (totally agree). Example items are: "During time after work, I don't think about work at all (psychological detachment), “[...] I do relaxing things" (relaxation), “[...], I do things that challenge me" (mastery) and "[...], I determine for myself how I will spend my time" (control). Cronbach's alphas for these scales varied between .76 (mastery at T1) and .86 (psychological detachment at T2).

Job performance. We used six items from the Finnish version of the Maslach Burnout Inventory as a proxy for self-reported task performance (Kalimo, Hakanen, \& ToppinenTanner, 2006). The items are designed to measure "personal achievement", defined as feelings of competence and successful achievement in one's work (Maslach, Jackson, \& Leiter, 1996). An example item is: "I feel I am making an effective contribution to what this organization does". Answers could range from 0 (= never) to 6 (= always). Cronbach's alphas were .82 at $\mathrm{T} 1$ and .84 at T2. Contextual performance was measured with three items from various existing 
questionnaires (Eisenberger et al., 2010; Goodman \& Svyantek, 1999; Staufenbiel \& Hartz, 2000) focusing on helpful behavior (e.g., "I help my colleagues when their work load increases") and engaging in actions beyond a person's formal job description (e.g., "I volunteer to do things not formally required by my job"). Answers could range from 1 (= very seldom or never) to 5 (= very often or always). Cronbach's alphas were .61 at T1 and .65 at T2 for the contextual performance scale. Adaptive performance was measured with three items developed by George and Zhou (2001) focusing on having innovative ideas, solving work problems creatively, and suggesting new ways of working. An example item is: "I come up with creative solutions to work problems". Participants responded on a frequency scale ranging from 1 (very seldom/never) to 5 (very often/always). Cronbach's alphas were .84 at T1 and .86 at T2.

\section{Data analyses}

In our preliminary analyses, we studied the mean level and rank order stability of each leisure activity between $\mathrm{T} 1$ and $\mathrm{T} 2$ using paired-samples $t$-tests and test-retest correlations (i.e., autocorrelation), respectively. This was done to examine the stability of leisure activity participation across the one-year time span which was considered a prerequisite for the next set of analyses.

To identify possible homogeneous subpopulations in the sample differing from each other in the longitudinal leisure activity profiles we used LPA (research question 1). Specifically, the observed scores for the aforementioned five leisure activities at T1 and T2 were entered simultaneously into the LPA analysis. In other words, both T1 and T2 data were utilized to form the longitudinal leisure activity profiles in which the gathered information from both time points is combined into one classification. Hence, these profiles are neither representative of cross-sectional leisure activity profiles analysed at $\mathrm{T} 1$ and at $\mathrm{T} 2$ separately nor do they 
represent either $\mathrm{T} 1$ or $\mathrm{T} 2$ leisure activity profiles per se. The resulting profiles represent longitudinal leisure activity profiles across $\mathrm{T} 1$ and $\mathrm{T} 2$.

Because LPA is a model-based method, alternative latent profile group-solutions can be compared against each other with rigorous tests (Lubke \& Muthén, 2005). Accordingly, to determine the most appropriate number of latent leisure activity profiles, we evaluated the model fit for each latent profile group-solution (1-5) using log likelihood, the adjusted Bayesian Information Criterion (aBIC), entropy, and the Lo-Mendell-Rubin adjusted likelihood ratio test (LMR). When comparing different group-solutions against each other, smaller log likelihood and aBIC values, and higher entropy values, reflect better fit of a given group solution with the data (Muthén, 1998-2004; Nylund, Asparouhov, \& Muthén, 2007). LMR compares adjacent groups (i.e., one versus two groups, two versus three groups etc.) against each other, with a significant $p$ value indicating improvement in model fit as the number of groups increases with one. Besides log likelihood, aBIC, entropy, and LMR values, it is also important to consider the average latent class probabilities for each participant's most likely latent group membership. This ensures that the participants can be reliably classified into the identified latent profile groups.

To specify how the longitudinal leisure activity profiles identified differed regarding each leisure activity separately at T1 and T2, we used Univariate Analysis of Variance (ANOVA). Differences between the leisure activity profiles identified in sample demographics were examined using either cross-tabulation with $\chi^{2}$ test for categorical variables (gender, marital status, education, occupational status) or ANOVAs for continuous variables (age, number of children living at home, weekly working hours). To investigate the differences between the longitudinal leisure activity profiles in recovery experiences (research question 2) and job performance (research question 2) cross-sectionally and longitudinally (i.e., T1 and T2), we used the General Linear Model (GLM) for repeated measures. 
The use of GLM for repeated measures meant that we investigated each dependent variable (four recovery experiences and three job performance indicators) separately to see whether there was 1) a time effect (i.e. the level of variable in question either decreased or increased from $\mathrm{T} 1$ to $\mathrm{T} 2$ in the whole sample), 2) group effect (i.e. the level of variable in question at T1 and $\mathrm{T} 2$ was dependent on the longitudinal leisure activity profile membership), or 3) a time $\mathrm{x}$ group interaction effect (i.e. the level of variable in question remained stable, decreased or increased from $\mathrm{T} 1$ to $\mathrm{T} 2$ depending on the longitudinal leisure activity profile membership). Hence, we did altogether seven GLM for repeated measures analyses were each recovery experience, and each job performance indicator at $\mathrm{T} 1$ and at $\mathrm{T} 2$ was included in the analysis as a dependent variable, that is, as a within subject factor.

\section{Results}

\section{Mean level and rank order stability of leisure activities}

As shown in Table 1, the mean levels of each separate leisure activity participation from $\mathrm{T} 1$ to T2 were clearly stable. This suggests that in our study, we mainly captured behaviors related to people's leisure coping beliefs which are the result of the socialization process and which are rather stable across the life span (Iwasaki \& Mannell, 2000). For cultural activities, a very slight decrease from T1 to T2 was observed $(p=.05)$ while there was no change between T1 and T2 concerning intensive physical activities, physical activities in natural surroundings, social and creative activities. Physical and social activities were reportedly engaged in on average once a week, cultural and creative activities on average once a month. Similarly, strong and highly significant autocorrelations $(r=.55-.71)$ were observed for each leisure activity between $\mathrm{T} 1$ and $\mathrm{T} 2$. This means that the more often participants engaged in certain leisure activities at $\mathrm{T} 1$, the more likely they were to engage in the same activity at $\mathrm{T} 2$. Cultural activities showed the least stability, suggesting some fluctuation over one year. Overall, these 
results suggest that both mean level and rank order stability for each separate leisure activity were high in the present sample, meeting the prerequisite for investigating stable longitudinal leisure activity profiles (cf. page 7).

\section{Research question 1: Longitudinal leisure activity profiles}

As shown in Table 2, we estimated five group solutions. The log likelihood and aBIC values favoured a five-group solution. Entropy was highest for the one and two-group solutions, whereas LMR values indicated that increasing latent groups by one improved the model fit up to four groups. The average latent group probabilities were acceptable (i.e., above .80) for every latent group in each of the estimated group solutions.

As the different information criteria did not yield a clear basis upon which to decide the optimal number of latent leisure activity profiles, we relied on inspecting aBIC and LMR values in combination. According to Nylund et al. (2007, p. 564), 'BIC is the most consistent IC [information criterion] among those considered for correctly identifying the number of classes'. Hence, we chose the group solution with the lowest aBIC value as well as a significant LMR value. This was the four-group solution. This decision was further supported by our observation of only a modest decrease from the three to four and from four to five group solutions in the absolute log likelihood values compared to the much steeper decrease from one to two and from two to three group solutions. This flattening out of absolute log likelihood values with large samples $(n=500-1000)$ is deemed an indication of approaching the best group solution (Nylund et al., 2007).

The four longitudinal leisure activity profiles identified are illustrated in Figure 1. It can be seen that within each profile the scores for each leisure activity between T1 and T2 are very similar. The significant differences between the profiles in each distinct leisure activity at T1 and $\mathrm{T} 2$ are in turn reported in Table 3. Together Figure 1 and Table 3 show that these leisure 
activity profiles were stable over time. The largest profile group comprised $46 \%(n=379)$ of the participants. In this group's profile participation in physical (both intensive and in natural surroundings) and social activities was above the sample average. Hence this profile was named "Social Sports(wo)men". The second largest profile group comprised 23\% $(n=192)$ of the participants. Their engagement in all leisure activities studied and particularly in creative activities was well above the sample average, hence the name "Active Artists" was used. The two smaller profile groups were labeled "Socially \& Culturally Inactives" $(17 \%, n=141)$ and "Inactive Soloists" (14\%, $n=119)$. Socially \& Culturally Inactives reported around sample average engagement in physical activities but below average engagement in social, cultural and creative activities. Inactive Soloists reported very low engagement in physical activities (both intensive and nature), somewhat below average engagement in social activities and around sample average engagement in cultural and creative activities.

In sample demographics, there were only a few differences between the longitudinal leisure activity profiles. The most obvious difference between the profiles concerned gender, with significantly more women among the Social Sports(wo)men (68\%) and more men among Socially \& Culturally Inactives (66\%) and Inactive Soloists (56\%) than expected based on sample distribution (59\% women, $41 \%$ men) $\left[\chi^{2}(3)=34.26, p<.001\right]$. Social Sports(wo)men were slightly younger than Socially \& Culturally Inactives [means 46.39 vs. 49.15, respectively, $F(3,807)=2.852, p=.036]$, and there were more co-habiting participants than expected based on sample distribution among Socially \& Culturally Inactives [90\% vs. $81 \%$ in the whole sample, $\left.\chi^{2}(3)=8.51, p=.037\right]$. 


\section{Research question 2: Differences in recovery experiences between the longitudinal leisure}

activity profiles

The results of GLM for repeated measures are reported in Table 4. In these analyses, each recovery experience at a time was set as a within-subject factor (constituting of T1 and T2 measurements), the longitudinal leisure activity profile group was set as a between-subject factor and sample demographics (i.e., gender, marital status, education, occupational status, age, number of children living at home and weekly working hours) were included in the model as covariates. We did not observe time x group interaction effects in any of these analyses which means that the possible stability, decrease or increase from $\mathrm{T} 1$ to $\mathrm{T} 2$ in each recovery experience did not depend on the longitudinal leisure activity profile membership but was observed for whole sample. Hence, below we report only the main effects of time and group, that is, longitudinal leisure activity profile membership, of which the latter played the most important role.

Recovery experiences. There were no significant time effects (i.e., no mean level increase or decrease between $\mathrm{T} 1$ and T2) in relaxation during off-job time. However, relaxation differed between the leisure activity profiles. Across time, it was lower among Socially \& Culturally Inactives and Inactive Soloists than among Social Sports(wo)men and Active Artists. Like relaxation detachment also showed no decrease or increase from T1 to T2, and Active Artists reported more detachment than Socially \& Culturally Inactives and Inactive Soloists across time. The observed significant time effect for mastery means that mastery decreased slightly from $\mathrm{T} 1$ to $\mathrm{T} 2(M=3.43$ at $\mathrm{T} 1$ and $M=3.27$ at $\mathrm{T} 2)$. There were also differences in mastery between the longitudinal leisure activity profiles: Active Artists reported more mastery across time than the other three leisure activity profile groups. Regarding control during free time, Social Sports(wo)men and Active Artists reported more control than did Inactive Soloists across time, and in the whole sample no increase or decrease was observed from T1 to T2. 


\section{Research question 3: Differences in job performance between the longitudinal leisure}

activity profiles

The results of GLM for repeated measures are reported in Table 4. As for recovery experiences, in these analyses, each job performance indicator at a time was set as a within-subject factor (constituting of T1 and T2 measurements), the longitudinal leisure activity profile group was set as a between-subject factor and sample demographics (see above) were included in the model as covariates. We did not observe time $\mathrm{x}$ group interaction effects in any of these analyses. Hence, below we report only the main effects of time and group, that is, longitudinal leisure activity profile membership, of which the latter played the most important role also here.

The only time effect was observed for contextual performance which showed a very modest but significant decrease across time $(M=3.42$ at $\mathrm{T} 1$ and $M=3.41$ at T2). Task-, contextualand adaptive performance differed between the longitudinal leisure activity profiles. Across T1 and T2 Active Artists and Social Sports(wo)men reported higher task performance than did Socially \& Culturally Inactives. Active Artists scored also higher than Inactive Soloists in this performance type. In contextual and adaptive performance, Active Artists reported higher levels of performance than did all other groups.

\section{Discussion}

The present longitudinal study on a large sample of Finnish employees was designed to identify groups of people with similar patterns of leisure activities over time, called longitudinal leisure activity profiles, and to determine whether those belonging to different profiles also differed in their recovery experiences and job performance across a one-year time span. The mean level and correlation analyses showed that engagement in leisure activities was relatively stable across time. This corroborates earlier findings (e.g., Iso-Ahola, Jackson, \& Dunn, 1994), and 
implies that changing people's leisure behavior may be difficult to achieve in adulthood (for a review of the effectiveness of lifestyle interventions, see Dunn, Andersen, \& Jakicic, 1998). Since in earlier studies (e.g., Hancox, Milne, \& Poulton, 2004) engagement in certain leisure activities, such as watching television or exercising, has been connected to a wide variety of long-term health outcomes, scrutinizing and promoting healthy leisure behavior at an early age seems very useful.

\section{Research question 1: Characteristic longitudinal profiles of engagement in leisure activities do exist}

We used LPA to ascertain whether participants could be divided into groups distinguished by their preferred pattern of leisure activities over time. We identified four profiles. The largest profile, Social Sports(wo)men (46\%) favored intensive physical activities and physical activities in natural surroundings while (apparently) avoiding creative and cultural activities. They also engaged in social activities frequently (more than once per week). The second largest profile, Active Artists (23\%) tended to engage in all activities and particularly in creative activities. Inactive Soloists (17\%) constituted the opposite to Social Sports(wo)men profile, spending particularly little time on physical activities. The last and smallest profile, Socially \& Culturally Inactives (14\%) reported average levels of engagement in physical activities, but very little time spent on social, cultural, and creative activities. Overall, every leisure activity discriminated between those within or outside the profiles, but the most pronounced differences were observed between intensive physical and creative activities.

An earlier study found that intensity (i.e., high versus low) is a distinctive, important feature of leisure activity engagement (Leuty et al., 2015). Leuty et al. (2015) also identified a small group of participants with a moderate interest in almost all activities except physical and social activities which corresponds fairly well to our "Inactive Soloists"-profile. Members of this 
profile may also have devoted their off-job time to other activities, for instance household chores, caregiving within the family or long commutes from work, which were not explicitly measured in our study.

\section{Research question 2 and 3: Longitudinal leisure activity profiles relate differentially and systematically to recovery experiences and job performance across time}

Our results showed that an active lifestyle characterized by a wide variety of activities - here exemplified most clearly by Active Artists (constituting a quarter of the sample) - was related to beneficial recovery experiences during off-job time and high job performance across a oneyear time span. This finding corroborates results from a plethora of earlier studies emphasizing the benefits of an active lifestyle (for an overview, see Henderson \& Bialeschki, 2005). Moreover, Social Sports(wo)men were similar to Active Artists concerning recovery experiences, namely relaxation and control, and one type of job performance, namely, task performance suggesting that physical and social leisure activities also seem to make a good combination.

Consequently, multiple leisure activities seem to expand the possibilities for experiencing diverse recovery experiences. Participants who invest their time in many different off-job activities and particularly creative activities also report the highest job performance. Our results seem to lend support to the expansion approach (see Barnett \& Hyde, 2001), according to which activities which are voluntary and desirable do not deplete but replenish our resources, even if they are effortful, such as physical exercise.

Least favorable outcomes were seen among Inactive Soloists and Socially \& Culturally Inactives, profiles which were characterized by relatively little engagement in several leisure activities. For Socially \& Culturally Inactives particularly few social, cultural, and creative activities were reported and Inactive Soloists undertook few physical activities and social 
activities. Socially \& Culturally Inactives were slightly older and more often co-habiting than those in other profiles. Members of both groups were also more often male than female. These background differences may also partly explain the differences between these profiles. It is widely known that cultural/artistic preferences and activities are more typical among women than men (e.g., Su, Rounds, \& Armstrong, 2009). Men also tend to have a more sedentary lifestyle, especially when they are older (e.g., Harvey, Chastin \& Skelton, 2015). Even though we did not find significant differences in occupation, future research could study in more detail whether mental load, strain at work or personality traits can explain these leisure preferences (see also Brandstätter, 1994). It may also be speculated that this group was composed of people experiencing high strain at work and at home (e.g., burdensome household chores, caregiving tasks, long commuting time between the work place and home), reducing their abilities to recover and perform well. Prolonged fatigue which leads to both reduced engagement in work and leisure is conceivable, too.

\section{Limitations and suggestions for future research}

The categories for leisure activities we measured were fairly broad, encompassing many more specific activities than we could possibly study as part of an already large test battery. Future studies could assess a more diverse set of leisure activities. For instance, Inactive Soloists tended to spend little time on all activities examined. The obvious question thus concerns how they spend their time, possibly on chores such as household chores or childcare, or on digital activities such as surfing the web or social media use. Adding these activities to the list of leisure activities may yield a more detailed picture of people's activities outside work. It may also be that Socially \& Culturally Inactives and Inactive Soloists faced higher job demands or had to work overtime, drastically limiting their time and energy to engage in leisure activities. These demands may act as moderators between leisure, recovery, and performance. A diary 
study among police officers, for instance, found that on highly stressful days at work, engagement in sports activities diminished even though the officers usually enjoyed these activities (Sonnentag \& Jelden, 2009). Effortful leisure activities such as sports or voluntary work require a certain amount of self-regulation, defined as cognitive processes necessary to achieve goals, resist temptations and impulses (Muraven \& Baumeister, 2000). If people's abilities for self-regulation are depleted by stressful work, it may be very difficult for them to start engaging in effortful leisure activities in the evening after work or during the weekend. And what if employees engage in leisure activities which deplete their cognitive or emotional resources during leisure time so that working ability is temporarily impaired? Or if they are exposed to physical risks during their free time (e.g., Brymer, 2010; Creyer, Ross, \& Evers, 2003)? These potential negative effects of leisure on performance constitute another interesting avenue for future studies.

In addition, we did not measure engagement in low-effort activities such as watching television or reading as we expected very little variation in the responses, which could range from "daily" to "never", assuming that every person spends at least some time on low-effort activities every day. To overcome this problem, future research could use a diary design and elicit the exact amount of daily engagement in leisure activities. If a wide array of leisure activities is assessed, factor analysis could be used to cluster these activities into broader categories of activities. This could afford a better general understanding of a complex field and a taxonomy for leisure activities (Brajša-Žganec et al., 2011). It would also further validate our approach of measuring a smaller set of broader leisure activities.

Another shortcoming of our study is the low internal consistency of the contextual performance scale. However, it is common that short scales intended to capture broad, multidimensional constructs have rather low internal consistencies (Streiner, 2003). As contextual performance concerns behaviors intended to benefit colleagues or the company, it 
seems well suited to be assessed by colleagues or other people in the company who can observe an employee's behavior at work in future research. Task performance could also be evaluated by line managers or colleagues to overcome people's tendency to overestimate it.

Interesting new insights on leisure may also be obtained by combining people's self-reports with data from activity trackers measuring people's activity level and potentially even including information on a person's bodily functions (e.g., heart rate (variability), blood pressure) and location, thereby providing further evidence of the role of leisure activities in recovery. Our results also suggest a common third factor explaining the relationship between heavy investment in free time activities and good job performance. Possible candidates are personality traits such as extroversion, sensation seeking or motivation orientation (for an overview of studies on personality and leisure, see Barnett, 2006). Future research could explore these potential relationships in more detail by also assessing personality variables.

\section{Strengths and contributions to the literature}

Our study contributes to the literature in four ways. Firstly, it is one of the first studies to focus on longitudinal leisure activity profiles. By analyzing combinations of different types of leisure activities over time, our study takes into account real life processes where leisure activities do not occur in a vacuum but concurrently or closely related in time. Secondly, having a longitudinal perspective we were able to capture the simultaneous reflections of leisure activities in recovery experiences and job performance across time. This approach revealed that leisure activity profiles were fairly stable rather than fluctuating across a one-year period and how the profiles related to recovery experiences and job performance also measured and modelled longitudinally over time.

Thirdly, many studies within this field have used either rather broad samples, including, for instance, employees, students, and retirees, or have targeted specific minority groups (e.g., 
Caldwell, \& Gilbert, 2009; Freeman, \& Zabriskie, 2003; Kivel, \& Kleiber, 2000). In fact, employees have rarely been the focus of studies in this field. Consequently, links between leisure activities and job-related outcomes have rarely been assessed.

Fourthly, we tried to establish and strengthen existing links between work psychology and leisure sciences. In work psychology, free time has often been taken to be absence of work tasks and stress, frequently ignoring the fact that ceasing one's work task necessarily entails spending time on other activities. What has long been missing is an understanding of how time not spent on working is actually used and experienced. Leisure sciences has interesting insights to offer which are relevant for working life.

\section{Theoretical and practical implications}

Article 24 of the United Nations Universal Declaration of Human Rights stipulates that everyone has the right to rest and leisure. Thus, work should not intrude upon other life domains. Our study adds to the debate on work/non-work boundaries and provides an additional argument for the detrimental effect of permeable boundaries (Ashforth, Kreiner, \& Fugate, 2000; Kelly et al., 2008; Kinnunen et al., 2016). If work increasingly transgresses the boundaries of other life domains, engagement in leisure may be hampered. According to the results of our study, this is linked to suboptimal recovery experiences and lower performance at work. A related, yet under researched area is leisure time entering work. For instance, covert and overt use of social media websites or online games are very common nowadays and usually framed as counterproductive work behaviors (Friedman, 2001; Lim, 2002). However, some studies suggest that working people may engage in these behaviors to give themselves a break from demanding work and to recover from stress (e.g., Coker, 2011; Rieger et al., 2014). More research is warranted to arrive at a deeper understanding of the interface between work and 
leisure and the implications of vanishing boundaries between these fields (for an interesting discussion, see also Stebbins, 2015).

From an employer's point of view, granting employees regular time off work (undisturbed by work-related calls or emails) to engage in enjoyable activities can be considered beneficial for the company. Employers may stimulate engagement in healthy leisure activities, for example, by providing vouchers for sports activities (e.g., a subscription to the gym or financial support for participating in sports courses) or organizing cultural and creative group activities for employees. Subsidizing theater or concert tickets or organizing courses in handicrafts or learning to play an instrument might encourage working people to become more active, sociable, and creative during their free time. When employing such organizational-level measures, however, the active involvement of employees and consideration of their opinions (e.g., choosing activities themselves) are crucial to yield beneficial results (Brough \& O'Driscoll, 2010; Nielsen, Randall, Holten, \& González, 2010). (e.g., Brough \& O'Driscoll, 2010; Nielsen, Randall, Holten, \& González, 2010). Given that preferences for engaging in leisure activities remain relatively stable across time, however, it would be most important to consider interventions at an early age, for example among novice workers starting their work careers after graduation, to establish healthy routines and leisure activity preferences.

\section{Conclusion}

The present study combines theoretical insights from work psychology and leisure sciences and provides a new perspective on the interface between leisure and work by using a personcentered approach to data analysis. We could show that preferences for leisure activities are relatively stable across a one-year period and that people can be grouped into four meaningful profiles of leisure activities differing in both intensity and variety. An active lifestyle, engagement in a wide array of activities, and particularly creative as well as physical activities 
seem to be conducive to efficient recovery after work as well as higher levels of job performance in the long-term. 


\section{References}

Amstad, F. T., \& Semmer, N. K. (2009). Recovery and the work-family interface. In P. Perrewé, J. Halbesleben \& C. Rose (Eds.), Current perspectives on job-stress recovery (pp. 125-166). Bingley: Emerald Group Publishing Limited.

Argyle, M. (1996). The social psychology of leisure. New York: Penguin Books.

Ashforth, B. E., Kreiner, G. E., \& Fugate, M. (2000). All in a day's work: Boundaries and micro role transitions. Academy of Management Review, 25(3), 472-491.

Beckers, D., van der Linden, D., Smulders, P. G. W., Kompier, M., Van Veldhoven, M. J. P. M., \& Van Yperen, N. W. (2004). Working overtime hours: Relations with fatigue, work motivation, and the quality of work. Journal of Occupational and Environmental Medicine, 46, 1282-1289.

Bennett, A. A., Gabriel, A. S., Calderwood, C., Dahling, J. J., \& Trougakos, J. P. (2016). Better together? Examining profiles of employee recovery experiences. Journal of Applied Psychology.

Barnett, L. A. (2006). Accounting for leisure preferences from within: The relative contributions of gender, race or ethnicity, personality, affective style, and motivational orientation. Journal of Leisure Research, 38(4), 445-474.

Barnett, R. C., \& Hyde, J. S. (2001). Women, men, work, and family. American Psychologist, 56(10), 781.

Baumeister, R.F., \& Leary, M.R. (1995). The need to belong: Desire for interpersonal attachment as a fundamental human motivation. Psychological Bulletin, 117, 497-529

Bergman, L. R., \& Lundh, L. G. (2015). The person-oriented approach: Roots and roads to the future. Journal for Person-Oriented Research, 1(1-2), 1-6.

Berman, M. G., Jonides, J., \& Kaplan, S. (2008). The cognitive benefits of interacting with nature. Psychological Science, 19(12), 1207-1212. 
Binnewies, C., Sonnentag, S., \& Mojza, E. J. (2009a). Daily performance at work: Feeling recovered in the morning as a predictor of day-level job performance. Journal of Organizational Behavior, 30(1), 67-93

Binnewies, C., Sonnentag, S., \& Mojza, E. J. (2009b). Feeling recovered and thinking about the good sides of one's work. Journal of Occupational Health Psychology, 14(3), 243256

Blasche, G. W., Arlinghaus, A., \& Dorner, T. E. (2014). Leisure opportunities and fatigue in employees: A large cross-sectional study. Leisure Sciences, 36(3), 235-250.

Brandstätter, H. (1994). Pleasure of leisure-pleasure of work: Personality makes the difference. Personality and Individual Differences, 16(6), 931-946.

Brajša-Žganec, A., Merkaš, M., \& Šverko, I. (2011). Quality of life and leisure activities: How do leisure activities contribute to subjective well-being? Social Indicators Research, 102(1), 81-91.

Brough, P., \& O'Driscoll, M. P. (2010). Organizational interventions for balancing work and home demands: An overview. Work \& Stress, 24(3), 280-297.

Brymer, Eric. (2010). Risk taking in extreme sports: A phenomenological perspective. Annals of Leisure Research, 13(1-2), 218-238.

Ryan, R. M., Weinstein, N., Bernstein, J., Brown, K. W., Mistretta, L., \& Gagne, M. (2010). Vitalizing effects of being outdoors and in nature. Journal of Environmental Psychology, 30(2), 159-168.

Caldwell, L. L., \& Gilbert, A. A. (2009). Leisure, health, and disability: A review and discussion. Canadian Journal of Community Mental Health, 9(2), 111-122

Charbonnier-Voirin, A., \& Roussel, P. (2012). Adaptive performance: A new scale to measure individual performance in organizations. Canadian Journal of Administrative Sciences/Revue Canadienne des Sciences de l'Administration, 29(3), 280-293 
Chick, G., \& Hood, R. D. (1996). Working and recreating with machines: Outdoor recreation choices among machine-tool workers in western Pennsylvania. Leisure Sciences, 18(4), 333-354.

Christiansen, C. H., \& Matuska, K. M. (2006). Lifestyle balance: A review of concepts and research. Journal of Occupational Science, 13(1), 49-61.

Coker, B. L. S. (2011). Freedom to surf: The positive effects of workplace Internet leisure browsing. New Technology, Work and Employment, 26(3), 238-247.

Creyer, E., Ross, W., \& Evers, D. (2003). Risky recreation: An exploration of factors influencing the likelihood of participation and the effects of experience. Leisure Studies, 22(3), 239-253.

Csikszentmihalyi, M. (1991). Flow: The psychology of optimal experience (Vol. 41). New York: Harper Perennial

Cuypers, K., Krokstad, S., Lingaas Holmen, T., Skjei Knudtsen, M., Olov Bygren, L., \& Holmen, J. (2011). Patterns of receptive and creative cultural activities and their association with perceived health, anxiety, depression and satisfaction with life among adults: the HUNT study, Norway. Journal of Epidemiology and Community Health.

Dahlgren, A., Kecklund, G., \& Åkerstedt, T. (2006). Overtime work and its effects on sleep, sleepiness, cortisol and blood pressure in an experimental field study. Scandinavian Journal of Work, Environment \& Health, 32, 318-327.

De Bloom, J., Geurts, S. A. E., \& Kompier, M. A. J. (2012). Effects of short vacations, vacation activities and experiences on employee health and well-being. Stress and Health, 28(4), 305-318.

De Bloom, J., Geurts, S. A. E., \& Kompier, M. A. J. (2013). Vacation (after-) effects on employee health and well-being, and the role of vacation activities, experiences and sleep. Journal of Happiness Studies, 14(2), 613-633. 
De Bloom, J., Geurts, S. A. E., Sonnentag, S., Taris, T., De Weerth, C., \& Kompier, M. A. J. (2011). How does a vacation from work affect employee health and well-being? Psychology \& Health, 26(12), 1606-1622.

Demerouti, E., Bakker, A. B., Geurts, S. A. E., \& Taris, T. W. (2009). Daily recovery from work-related effort during non-work time. In S. Sonnentag, P. L. Perrewé, \& D. C. Ganster (Eds.), Current perspectives on job-stress recovery: Research in occupational stress and well-being (Vol. 7, pp. 85-123). Bingley, UK: JAI Press

Demerouti, E., Taris, T. W., \& Bakker, A. B. (2007). Need for recovery, home-work interference and performance: Is lack of concentration the link? Journal of Vocational Behavior, 71(2), 204-220

Dormann, C., \& Zapf, D. (1999). Social support, social stressors at work, and depressive symptoms: Testing for main and moderating effects with structural equations in a threewave longitudinal study. Journal of Applied Psychology, 84, 874-884.

Dunn, A. L., Andersen, R. E., \& Jakicic, J. M. (1998). Lifestyle physical activity interventions: History, short- and long-term effects, and recommendations. American Journal of Preventive Medicine, 15(4), 398-412.

Eisenberger, R., Karagonlar, G., Stinglhamber, F., Neves, P., Becker, T. E., Gonzalez-Morales, M. G., \& Steiger-Mueller, M. (2010). Leader-member exchange and affective organizational commitment: The contribution of supervisor's organizational embodiment. Journal of Applied Psychology, 95, 1085-1103.

Eschleman, K. J., Madsen, J., Alarcon, G., \& Barelka, A. (2014). Benefiting from creative activity: The positive relationships between creative activity, recovery experiences, and performance-related outcomes. Journal of Occupational and Organizational Psychology, 87, 579-598. 
Feuerhahn, N., Sonnentag, S., \& Woll, A. (2014). Exercise after work, psychological mediators, and affect: A day-level study. European Journal of Work and Organizational Psychology, 23, 62-79.

Ford, M. T., Heinen, B. A., \& Langkamer, K. L. (2007). Work and family satisfaction and conflict: a meta-analysis of cross-domain relations. Journal of Applied Psychology, 92(1), 57-80.

Fredrickson, B.L. (2001). The role of positive emotions in positive psychology. The broadenand-build theory of positive emotions. American Psychologist, 56(3), 218-226.

Freeman, P., \& Zabriskie, R. B. (2003). Leisure and family functioning in adoptive families: Implications for therapeutic recreation. Therapeutic Recreation Journal, 37(1), 73-93.

Friedman, W. H. (2001). Virtual absenteeism. In J. D. Haynes (Ed.), Internet management issues: A global perspective (pp. 138-149). Hershey PA: Idea Group Publishing.

Friedman, H. S., Martin, L. R., Tucker, J. S., Criqui, M. H., Kern, M. L., \& Reynolds, C. A. (2008). Stability of physical activity across the lifespan. Journal of Health Psychology, 13(8), 1092- 1104.

George, J. M., \& Zhou, J. (2001). When openness to experience and conscientiousness are related to creative behavior: An interactional approach. Journal of Applied Psychology, $86(3), 513-524$.

Gerin, W., Pieper, C., Levy, R., \& Pickering, T.G. (1992). Social support in social interaction: a moderator of cardiovascular reactivity. Psychosomatic Medicine, 54, 324-336.

Geurts, S. A. E., \& Sonnentag, S. (2006). Recovery as an explanatory mechanism in the relation between acute stress reactions and chronic health impairment. Scandinavian Journal of Work, Environment \& Health, 32, 482-492. 
Gilboa, S., Shirom, A., Fried, Y., \& Cooper, C. L. (2008). A meta-analysis of work demand stressors and job performance: Examining main and moderating effects. Personnel Psychology, 61(2), 227-271.

Goodman, W. K., Geiger, A. M., \& Wolf, J. M. (2015). Differential links between leisure activities and depressive symptoms in unemployed individuals. Journal of Clinical Psychology, 72, 70-78.

Goodman, S. A., \& Svyantek, D. J. (1999). Person-organization fit and contextual performance: Do shared values matter? Journal of Vocational Behavior, 55, 254-275.

Guest, D. E. (2002). Perspectives on the study of work-life balance. Social Science Information, 41(2), 255-279.

Hahn, V.C., Binnewies, C., Sonnentag, S., \& Mojza, E.J. (2011). Learning how to recover from job stress: effects of a recovery training program on recovery, recovery-related selfefficacy, and well-being. Journal of Occupational Health Psychology, 16, 202-216.

Hale, C., J., Hannum, J. W., \& Espelage, D. L. (2005). Social support and physical health: The importance of belonging. Journal of American College Health, 53, 276-284.

Hancox, R. J., Milne, B. J., \& Poulton, R. Association between child and adolescent television viewing and adult health: A longitudinal birth cohort study. The Lancet, 364(9430), $257-262$.

Hansen, C. J., Stevens, L. C., \& Coast, J. R. (2001). Exercise duration and mood state: How much is enough to feel better? Health Psychology, 20(4), 267-275.

Hansmann, R., Hug, S.-M., \& Seeland, K. (2007). Restoration and stress relief through physical activities in forests and parks. Urban Forestry \& Urban Greening, 6(4), 213-225.

Harvey, J. A, Chastin, S. F. M., \& Skelton, D. A. (2015). How sedentary are older people? A systematic review of the amount of sedentary behavior. Journal of Aging and Physical Activity, 23, 471-87. 
Henderson, K. A., \& Bialeschki, M. D. (2005). Leisure and active lifestyles: Research reflections. Leisure Sciences, 27(5), 355-365.

Hilbrecht, M. (2007). Changing perspectives on the work-leisure relationship. Annals of Leisure Research, 10(3-4), 368-390.

Iso-Ahola, S. E. (1979). Basic dimensions of definitions of leisure. Journal of Leisure Research, 11(1), 28-39.

Iso-Ahola, S. E., Jackson, E. L., \& Dunn, E. (1994). Starting, ceasing, and replacing leisure activities over the human life-span. Journal of Leisure Research, 26(3), 227-249.

Iwasaki, Y. (2002). Exploring leisure coping processes: Roles of leisure activities and psychosocial functions of leisure coping. Annals of Leisure Research, 5(1), 27-50.

Iwasaki, Y., \& Mannell, R. C. (2000). Hierarchical dimensions of leisure stress coping. Leisure Sciences, 22(3), 163-181.

Iwasaki, Y., \& Schneider, I. E. (2003). Leisure, stress, and coping: An evolving area of inquiry. Leisure Sciences, 25, 107-113.

Iwasaki, Y., Zuzanek, J., \& Mannell, R. C. (2001). Social support, self-esteem, and sense of mastery as mediators of the relationships among physically active leisure, stress and health. Leisure/Loisir, 26(3-4), 257-287.

Kalimo, R., Hakanen, J., \& Toppinen-Tanner, S. (2006). Maslachin yleinen työuupumuksen arviointimenetelmä MBI-GS. [The Finnish version of the Maslach Burnout Inventory General Survey]. Helsinki: Finnish Institute of Occupational Health.

Kelly, E.L., Kossek, E.E., Hammer, L.B., Durham, M., Bray, J., Chermack, K., et al. (2008). Getting there from here: Research on the effects of work-family initiatives on workfamily conflict and business outcomes. Academy of Management Annals, 2(1), 305349. 
Kinnunen, U., Rantanen, J., De Bloom, J., Mauno, S., Feldt, T., \& Korpela, K. (2016). The role of of work-nonwork boundary management in work stress recovery. International Journal of Stress Management, 23(2), 99-123.

Kinnunen, U., Rantanen, J., Mauno, S., \& Peeters, M. (2013). Work-family interaction. In M. Peeters, J. de Jonge, \& T. Taris (Eds.), An introduction to contemporary work psychology (pp. 267-289). Hoboken, NJ: Wiley-Blackwell.

Kinnunen, Feldt, T., Siltaloppi, M., \& Sonnentag. S. (2011). Job Demands-Resources Model in the context of recovery: Testing recovery experiences as mediators. European Journal Work and Organizational Psychology, 20, 805-832.

Kivel, B. D., \& Kleiber, D. A. (2000). Leisure in the identity formation of lesbian/gay youth: Personal, but not social. Leisure Sciences, 22(4), 215-232

Koopmans, L., Bernaards, C. M., Hildebrandt, V. H., Schaufeli, W. B., de Vet, H. C. W., \& van der Beek, A. J. (2011). Conceptual frameworks of individual work performance: A systematic review. Journal of Occupational and Environmental Medicine, 53(8), 856866.

Korpela, K., \& Kinnunen, U. (2011). How is leisure time interacting with nature related to the need for recovery from work demands? Testing multiple mediators. Leisure Sciences, 33(1), 1-14.

Kuykendall, L., Tay, L., \& Ng, V. (2015). Leisure engagement and subjective well-being: A meta-analysis. Psychological Bulletin, 141(2), 364-403.

Leuty, M. E., Hansen, J.-I. C., \& Speaks, S. Z. (2015). Vocational and leisure interests a profilelevel approach to examining interests. Journal of Career Assessment, 24, 215-239.

Lim, V. K. G. (2002). The IT way of loafing on the job: Cyberloafing, neutralizing and organizational justice. Journal of Organizational Behavior, 23(5), 675-694. 
Lubke, G. H., \& Muthén, B. (2005). Investigating population heterogeneity with factor mixture models. Psychological Methods, 10, 21-39.

Major, D. A., \& Burke, R. J. (Eds.). (2013). Handbook of work life integration among professionals: Challenges and opportunities. Cheltenham, UK: Edward Elgar.

Mannell, R. C. (2007). Leisure, health and well-being. World Leisure Journal, 49(3), 114-128.

Martindale C. (1999). The biological basis of creativity. In: R. J. Sternberg (Ed). Handbook of creativity (pp. 137-152). Cambridge, UK: Cambridge University Press.

Maslach, C., Jackson, S.E., \& Leiter, M.P. (1996). Maslach Burnout Inventory (3rd ed.), Palo Alto, CA: Consulting Psychologists Press.

Meijman, T. F., \& Mulder, G. (1998). Psychological aspects of workload. In P. J. D. Drenth, H. Thierry \& C. J. de Wolff (Eds.), Handbook of work and organizational psychology (2nd edition). Work psychology (Vol. 2, pp. 5-33). Hove: Psychology Press

Motowidlo, S. J., \& Van Scotter, J. R. (1994). Evidence that task performance should be distinguished from contextual performance. Journal of Applied Psychology, 79(4), 475480.

Muraven, M., \& Baumeister, R.F. (2000). Self-regulation and depletion of limited resources: Does self-control resemble a muscle? Psychological Bulletin, 126, 247-259.

Muthén, B. O. (1998-2004). Mplus technical appendices. Los Angeles, CA: Muthén \& Muthén.

Newman, D. B., Tay, L., \& Diener, E. (2014). Leisure and subjective well-being: A model of psychological mechanisms as mediating factors. Journal of Happiness Studies, 15, $555-$ 578.

Nielsen, K., Randall, R., Holten, A. L., \& González, E. R. (2010). Conducting organizationallevel occupational health interventions: What works? Work \& Stress, 24(3), 234-259. 
Nylund, K. L., Asparouhov, T., \& Muthén, B. O. (2007). Deciding on the number of classes in latent class analysis and growth mixture modeling: A Monte Carlo simulation study. Structural Equation Modeling, 14, 535-569.

O'Driscoll, M. (1996). The interface between job and off job roles: Enhancement and conflict. In C. L. Cooper \& L. T. Robertson (Eds.), International review of industrial and organizational psychology (Vol. 11, pp. 279-306). Chichester: Wiley.

Passmore, A., \& French, D. (2001). Development and administration of a measure to assess adolescents' participation in leisure activities. Adolescence, 36(141), 67-75.

Penedo, F. J., \& Dahn, J. R. (2005). Exercise and well-being: A review of mental and physical health benefits associated with physical activity. Current Opinion in Psychiatry, 18(2), $189-193$

Pressman, S. D., Matthews, K. A., Cohen, S., Martire, L. M., Scheier, M. F., Baum, A., \& Schulz, R. (2009). Association of enjoyable leisure activities with psychological and physical well-being. Psychosomatic Medicine, 71(7), 725-732.

Reed, J., \& Ones, D. S. (2006). The effect of acute aerobic exercise on positive activated affect: A meta-analysis. Psychology of Sport and Exercise, 7, 477-514.

Richardson, M., Maspero, M., Golightly, D., Sheffield, D., Staples, V., \& Lumber, R. (2016). Nature: A new paradigm for well-being and ergonomics. Ergonomics, 22, 1-14.

Rieger, D., Reinecke, L., Frischlich, L., \& Bente, G. (2014). Media entertainment and well $\square$ being—Linking hedonic and eudaimonic entertainment experience to media $\square$ induced recovery and vitality. Journal of Communication, 64(3), 456-478.

Rook, J. W., \& Zijlstra, F. R. H. (2006). The contribution of various types of activities to recovery. European Journal of Work and Organizational Psychology, 15, 218-240

Ryan, R.M., \& Deci, E.L. (2000). Self-determination theory and the facilitation of intrinsic motivation, social development, and well-being. American Psychologist, 55, 68-78 
Sluiter, J. K., De Croon, E. M., Meijman, T. F., \& Frings-Dresen, M. H. W. (2003). Need for recovery from work related fatigue and its role in the development and prediction of subjective health complaints. Occupational and Environmental Medicine, 60(1), 62-70.

Snir, R., \& Harpaz, I. (2002). Work-leisure relations: Leisure orientation and the meaning of work. Journal of Leisure Research, 34, 178-203.

Sonnentag, S. (2001). Work, recovery activities, and individual well-being: A diary study. Journal of Occupational Health Psychology, 6, 196-210.

Sonnentag, S., Arbeus, H., Mahn, C., \& Fritz, C. (2014). Exhaustion and lack of psychological detachment from work during off-job time: Moderator effects of time pressure and leisure experiences. Journal of Occupational Health Psychology, 19(2), 206-216.

Sonnentag, S., \& Fritz, C. (2007). The recovery experience questionnaire: Development and validation of a measure for assessing recuperation and unwinding from work. Journal of Occupational Health Psychology, 12, 204-221.

Sonnentag, S. (2003). Recovery, work engagement, and proactive behavior: A new look at the interface between nonwork and work. Journal of Applied Psychology, 88(3), 518-528

Sonnentag, S., \& Jelden, S. (2009). Job stressors and the pursuit of sport activities: A day-level perspective. Journal of Occupational Health Psychology, 14, 165-181.

Staines, G. L. (1980). Spillover versus compensation: A review of the literature on the relationship between work and nonwork. Human Relations, 33(2), 111-129.

Staufenbiel, T. \& Hartz, C. (2000). Organizational citizenship behavior: Entwicklung und erste Validierung eines Meßinstruments. [OCB: Development and validation of an instrument]. Diagnostica, 46, 73-83.

Stebbins, R. A. (2001). Serious leisure. Society, 38(4), 53-57.

Stebbins, R. A. (2015). Between work and leisure: The common ground of two separate worlds. Herndon (VA): Transaction Publishers. 
Streiner, D. L. (2003). Being inconsistent about consistency: When coefficient alpha does and doesn't matter. Journal of Personality Assessment, 80(3), 217-222.

Su, R., Rounds, J., \& Armstrong, P. I. (2009). Men and things, women and people: A metaanalysis of sex differences in interests. Psychological Bulletin, 135, 859-884.

Super, D. E. (1980). A life-span, life-space approach to career development. Journal of Vocational Behavior, 16, 282-298.

Ten Brummelhuis, L. L., \& Bakker, A. B. (2012). Staying engaged during the week: The effect of off-job activities on next day work engagement. Journal of Occupational Health Psychology, 17, 445-455.

Tinsley, H. E., \& Eldredge, B. D. (1995). Psychological benefits of leisure participation: A taxonomy of leisure activities based on their need-gratifying properties. Journal of Counseling Psychology, 42(2), 123-132.

Trougakos, J. P., Beal, D. J., Green, S. G., \& Weiss, H. M. (2008). Making the break count: An episodic examination of recovery activities, emotional experiences, and positive affective displays. Academy of Management Journal, 51(1), 131-146.

Tucker, P., Dahlgren, A., Åkerstedt, T., \& Waterhouse, J. (2008). The impact of free-time activities on sleep, recovery and well-being. Applied Ergonomics, 39(5), 653-662.

Tuisku, K., Pulkki, R., Back, L., Ahola, K., Hakanen, J., \& Virtanen, M. (2012). Cultural leisure activities and well-being at work: A study among health care professionals. Journal of Applied Arts \& Health, 2(3), 273-287.

Tuisku, K., Virtanen, M., Bloom, J. D., \& Kinnunen, U. (2016). Cultural leisure activities, recovery and work engagement among hospital employees. Industrial Health, 54(3), 254-262. 
Volman, F. E., Bakker, A. B., \& Xanthopoulou, D. (2012). Recovery at home and performance at work: A diary study on self-family facilitation. European Journal of Work and Organizational Psychology, 22(2), 218-234.

Wang, M., Sinclair, R., Zhou, L., \& Sears, L. (2013). Person-centered analysis. Methods, applications, and implications for occupational health psychology. In L. Tetrick, M. Wang, \& R. Sinclair (Eds.), Research methods in occupational health psychology: Measurement, design, and data analysis (pp. 249 -373). New York, NY: Routledge.

Waterman, A. (2005). When effort is enjoyed: Two studies of intrinsic motivation for personally salient activities. Motivation and Emotion, 29(3), 165-188.

Wilson, M. (2002). Six views of embodied cognition. Psychonomic Bulletin \& Review, 9(4), 625-636.

Winwood, P. C., Bakker, A. B., \& Winefield, A. H. (2007). An investigation of the role of nonwork-time behavior in buffering the effects of work strain. Journal of Occupational and Environmental Medicine, 49 (8), 862-871

Zawadzki, M. J., Smyth, J. M., \& Costigan, H. J. (2015). Real-time associations between engaging in leisure and daily health and well-being. Annals of Behavioral Medicine, 49(4), 605-615.

Zedeck, S., \& Mosier, K. L. (1990). Work in the family and employing organization. American Psychologist, 45(2), 240-251. 
Table 1. Mean level and rank-order stability of each single leisure activity participation between Time 1 and Time $2(n=831)$.

\begin{tabular}{lcccc}
\hline Activity & $\begin{array}{c}\text { Time 1 } \\
M(S D)\end{array}$ & $\begin{array}{c}\text { Time 2 } \\
M(S D)\end{array}$ & $\begin{array}{c}\text { Time } \\
\text { effect } \\
t \text {-value }\end{array}$ & $\begin{array}{c}\text { Autocorrelation } \\
\text { between Time 1 and } \\
\text { Time 2 }\end{array}$ \\
\hline Intensive physical & 4.53 & 4.47 & 1.50 & $.68^{* * *}$ \\
Physical in natural & $(1.25)$ & $(1.24)$ & & $.66^{* * *}$ \\
surroundings & 4.30 & 4.28 & 0.40 & $.66^{* * *}$ \\
Social & $(1.30)$ & $(1.30)$ & & $.55^{* * *}$ \\
Cultural & 4.44 & 4.39 & 1.69 & $.71^{* * *}$ \\
Creative & $(1.19)$ & $(1.19)$ & & \\
& 2.25 & 2.18 & $1.97 *$ & \\
\hline
\end{tabular}

$* p<.05, * * * p<.001$ 
Table 2. Fit indices for estimated group solutions of longitudinal leisure activity profiles

\begin{tabular}{cccccc}
\hline $\begin{array}{c}\text { Number } \\
\text { of } \\
\text { groups }\end{array}$ & $\begin{array}{c}\text { Log } \\
\text { likelihood }\end{array}$ & aBIC & Entropy & $\begin{array}{c}\text { LMR } \\
p \\
\text { value }\end{array}$ & $\begin{array}{c}\text { Average latent group } \\
\text { probabilities }\end{array}$ \\
\hline & & & & & \\
1 & -13764.11 & 27599.15 & - & - & - \\
2 & -13220.63 & 26551.22 & .89 & .000 & $.94 / .98$ \\
3 & -12852.98 & 25854.93 & .89 & .000 & $.93 / .96 / .94$ \\
$\mathbf{4}$ & $\mathbf{- 1 2 7 1 6 . 3 7}$ & $\mathbf{2 5 6 2 0 . 7 2}$ & $\mathbf{. 8 4}$ & $\mathbf{. 0 0 0}$ & $\mathbf{. 8 4 / . 9 4 / . 9 4 / . 9 1}$ \\
5 & -12599.38 & 25425.76 & .87 & .613 & $.91 / .90 / .87 / .91 / .95$ \\
\hline
\end{tabular}

Note. aBIC $=$ Sample size adjusted Bayesian Information Criterion. LMR = Lo-Mendell-

Rubin adjusted likelihood ratio test. The figures in bold face show the group solution chosen to represent the best fit with the data. 
Table 3. Means $(M)$ and standard deviations $(S D)$ for each separate leisure activity for the four longitudinal leisure activity profiles identified

\begin{tabular}{|c|c|c|c|c|c|c|c|}
\hline & $\begin{array}{c}\text { Whole } \\
\text { sample } \\
n=831 \\
M(S D)\end{array}$ & $\begin{array}{c}1 \\
\text { Social Sports(wo)men } \\
n=379 \\
M(S D)\end{array}$ & $\begin{array}{c}2 \\
\text { Active Artists } \\
n=192 \\
M(S D)\end{array}$ & $\begin{array}{c}3 \\
\text { Socially \& } \\
\text { Culturally Inactives } \\
n=141 \\
M(S D)\end{array}$ & $\begin{array}{c}4 \\
\text { Inactive Soloists } \\
n=119 \\
M(S D)\end{array}$ & $\begin{array}{c}F \text { value }(d f), \\
p<.001 \text { for all } \\
\text { variables }\end{array}$ & $\begin{array}{l}\text { Bonferroni } \\
\text { pairwise } \\
\text { comparisons } \\
\text { between the } \\
\text { profiles }\end{array}$ \\
\hline \multicolumn{8}{|l|}{ Time 1 activities } \\
\hline Intensive physical & $4.53(1.25)$ & $4.98(0.83)$ & $4.85(0.95)$ & $4.67(0.73)$ & $2.39(1.02)$ & $282.04(3,827)$ & $4<1,2,3 ; 3<1$ \\
\hline $\begin{array}{l}\text { Physical in natural } \\
\text { surroundings }\end{array}$ & $4.30(1.30)$ & $4.80(0.96)$ & $4.56(1.16)$ & $4.01(1.16)$ & $2.66(1.19)$ & $126.66(3,827)$ & $4<3<1,2$ \\
\hline Social & $4.44(1.19)$ & $4.88(0.79)$ & $4.91(0.96)$ & $3.06(0.95)$ & $3.92(1.34)$ & $153.06(3,827)$ & $3<4<1,2$ \\
\hline Cultural & $2.25(1.10)$ & $2.33(0.98)$ & $2.71(1.24)$ & $1.57(0.87)$ & $2.03(1.02)$ & $35.37(3,827)$ & $3<4<1<2$ \\
\hline Creative & $2.29(1.60)$ & $1.50(0.73)$ & $4.61(1.02)$ & $1.41(0.80)$ & $2.11(1.38)$ & $529.52(3,827)$ & $1,3<4<2$ \\
\hline \multicolumn{8}{|l|}{ Time 2 activities } \\
\hline Intensive physical & $4.47(1.24)$ & $4.89(0.88)$ & $4.90(0.85)$ & $4.48(0.95)$ & $2.48(1.13)$ & $223.81(3,827)$ & $4<3<1,2$ \\
\hline $\begin{array}{l}\text { Physical in natural } \\
\text { surroundings }\end{array}$ & $4.28(1.30)$ & $4.72(1.03)$ & $4.53(1.15)$ & $4.07(1.18)$ & $2.77(1.29)$ & $95.62(3,827)$ & $4<3<1,2$ \\
\hline Social & $4.39(1.19)$ & $4.82(0.85)$ & $4.86(0.94)$ & $3.02(0.83)$ & $3.86(1.38)$ & $148.02(3,827)$ & $3<4<1,2$ \\
\hline Cultural & $2.18(1.06)$ & $2.26(0.98)$ & $2.64(1.14)$ & $1.49(0.67)$ & $1.97(1.06)$ & $39.37(3,827)$ & $3<4<1<2$ \\
\hline Creative & $2.34(1.59)$ & $1.67(0.95)$ & $4.35(1.30)$ & $1.44(0.94)$ & $2.30(1.48)$ & $279.13(3,827)$ & $1,3<4<2$ \\
\hline
\end{tabular}


Table 4. Main effects of time and longitudinal leisure activity profile group on recovery experiences and job performance

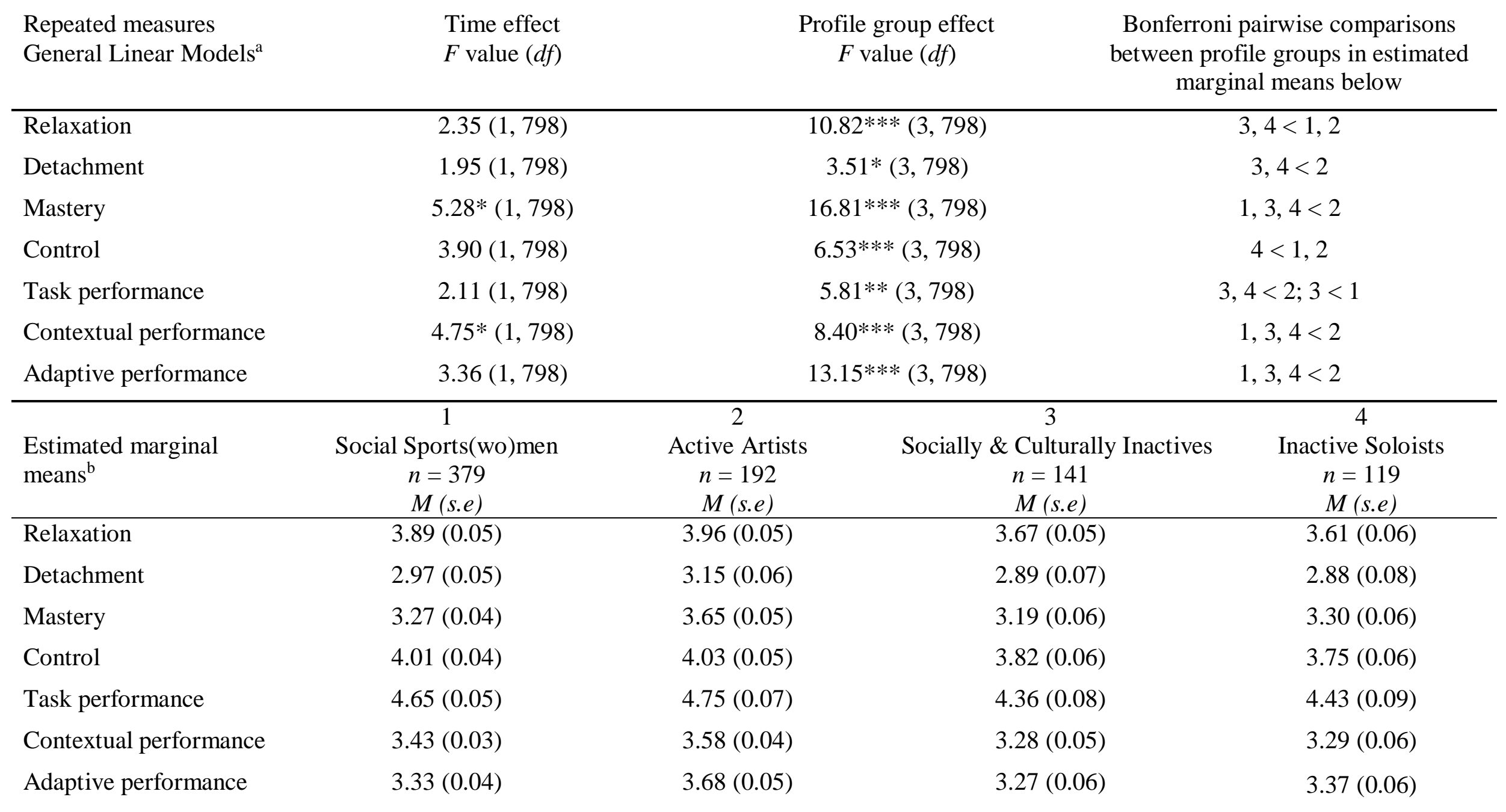

Note. $* p<.05, * * p<.01, * * * p<.001,{ }^{\text {a }}$ Performed separately for each variable in question based on measurements at Time 1 and Time 2 and including sample demographics (gender, marital status, education, occupational status, age, number of children living at home and weekly working hours) as covariates, ${ }^{\mathrm{b}}$ These means are model based estimated averages from Time 1 and Time 2 data 


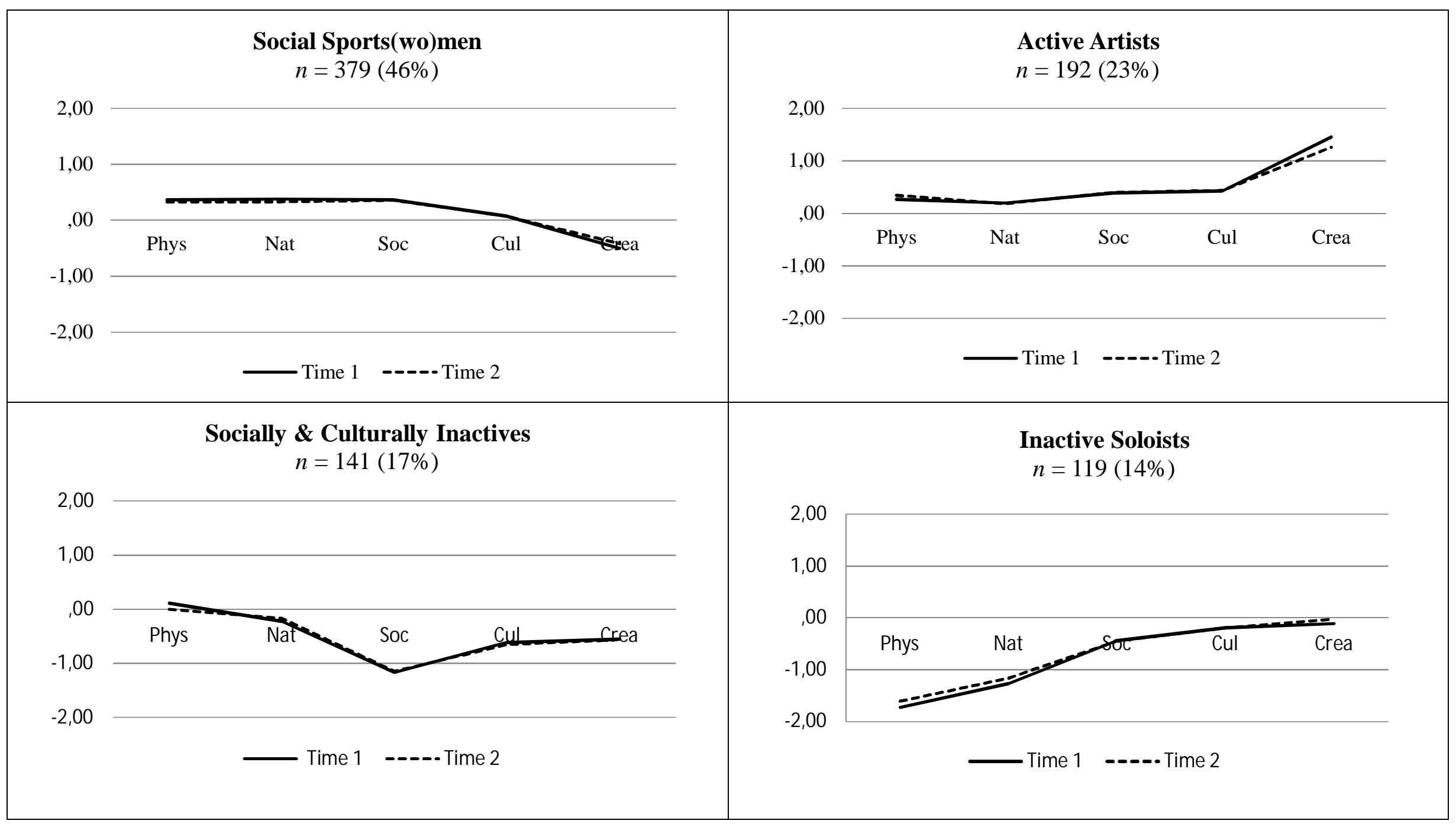

Figure 1. Identified longitudinal leisure activity profiles and their standardized scores (i.e., raw scores of each variable is transformed into a distribution where sample mean is zero and standard deviation is 1 ) in each leisure activity participation variable at Time 1 and Time 2 . Phys $=$ Physical activities, Nat $=$ Physical activities in natural surroundings, Soc $=$ Social activities, Cul $=$ Cultural activities, Crea $=$ Creative activities . 